\title{
Kontribusi Zakat untuk Pembangunan Daerah Tertinggal di Kabupaten Lebak Banten
}

\author{
Muhammad Helmi Fahrozi, ${ }^{1}$ Suprima, ${ }^{2}$ Rostania Nur Asiyah ${ }^{3}$ \\ Fakultas Hukum Universitas Pembangunan Nasional “Veteran” Jakarta \\ doi https://doi.org/10.32507/mizan.v4i1.598
}

\begin{abstract}
Regional development efforts with the application of zakat is very possible to become a new instrument for maximum regional development. The development of zakat management in the regions is a potential to revive the economy of the local community. One of the government's claims about the area is the nomenclature which is classified as the farthest, outermost, to disadvantaged areas. Lebak Regency is one of the area of Banten Province which is claimed by the central government to be a backward area. This study aims to give examples to other regions that there are many opportunities and potential contributions of zakat as an instrument when managed with a variety of strong programs and regulations. By using a qualitative method and through a doctrinal approach conducted by interviewing relevant parties, and exploring the regulatory authority of zakat management in a juridical normative manner, this study shows that Lebak Regency as a disadvantaged region can change its status by no longer being a disadvantaged area. The contribution of zakat which is managed maximally by mustahiq in synergy with the local government.
\end{abstract}

Keywords: Management of Zakat, Development of Disadvantaged Areas, Regency of Lebak.

\begin{abstract}
Abstrak
Upaya pembangunan daerah dengan penerapan zakat sangat memungkinkan untuk menjadi instrumen baru guna pembangunan daerah secara maksimal. Pengembangan pengelolaan zakat di daerah adalah potensi untuk membangkitkan perekonomian masyarakat setempat. Salah satu klaim pemerintah tentang daerah adalah nomenklatur penamaan yang diklasifikasikan menjadi daerah terjauh, daerah terluar, hingga daerah tertinggal. Kabupaten Lebak menjadi salah satu daerah dari Provinsi Banten yang diklaim pemerintah pusat menjadi daerah tertinggal. Penelitian ini bertujuan untuk memberikan contoh kepada daerah lain bahwa banyak peluang dan potensi kontribusi zakat sebagai salah satu instrumen ketika dikelola dengan berbagai macam program dan regulasi yang kuat. Dengan menggunakan metode kualitatif dan melalui pendekatan doktrinal yang dilakukan dengan teknik wawancara kepada pihak yang terkait, serta menggali regulasi kewenangan pengelolaan zakat secara yuridis normatif, penelitian ini menunjukkan Kabupaten Lebak sebagai daerah tertinggal dapat merubah statusnya dengan tidak lagi menjadi daerah tertinggal. Dari kontribusi zakat yang dikelola dengan maksimal oleh mustahik yang bersinergi dengan pemerintah daerah.
\end{abstract}

Kata Kunci: Pengelolaan Zakat, Pembangunan Daerah Tertinggal, Kabupaten Lebak.

\section{0.}

* Naskah diterima tanggal: 17 Januari 2020, direvisi: 21 Februari 2020, disetujui untuk terbit: 2 Maret

1 Muhammad Helmi Fahrozi adalah Dosen bidang ilmu Hukum pada Fakultas Hukum Universitas Pembangunan Nasional “Veteran” Jakarta. E-mail: helmifakhrazi@upnvj.ac.id

${ }^{2}$ Suprima adalah Dosen bidang ilmu Hukum pada Fakultas Hukum Universitas Pembangunan Nasional “Veteran" Jakarta.

${ }^{3}$ Rostania Nur Asiyah adalah Dosen bidang ilmu Hukum pada Fakultas Hukum Universitas Pembangunan Nasional “Veteran” Jakarta. 


\section{A. PENDAHULUAN}

Potensi zakat dapat dijadikan solusi permasalahan sosial yang ada di tengah masyarakat, sehingga pelaksanaannya dapat dimanfaatkan dengan maksimal. ${ }^{4}$ Konsep zakat sangat erat kaitannya dengan aspek ekonomi, karena objek materi zakat adalah material yang sedikit banyaknya terkait dengan finansial. Aspek finansial yang dapat dimaksimalkan tersebut menjadi satu nafas dengan konsep dasar yang dianjurkan oleh ajaran Islam.

Sebagai salah satu kewajiban utama yang harus dilakukan oleh umat Muslim adalah membayar zakat. Orang kaya wajib menyisihkan sebagian harta atau bendanya untuk diberikan kepada orang lain. ${ }^{5}$ Dalam ajaran umat Islam terdapat larangan bagi seseorang menimbun harta pribadinya, oleh karena itu sangat dianjurkan bahwa sesama umat Muslim harus saling tolong menolong. ${ }^{6}$

Merujuk kepada data BPS (Badan Pusat Statistik) di Indonesia, bahwa jumlah penduduk miskin, baik di kota maupun pedesaan pada bulan Maret 2018 mengalami penurunan dibandingkan jumlah penduduk miskin pada bulan September 2017. Menurut BPS (2018) selama periode September 2017-Maret 2018, jumlah penduduk miskin di daerah perkotaan turun sebanyak 128,2 ribu orang (dari 10,27 juta orang pada September 2017 menjadi 10,14 juta orang pada Maret 2018), sementara di daerah perdesaan turun sebanyak 505 ribu orang (dari 16,31 juta orang pada September 2017 menjadi 15,81 juta orang pada Maret 2018).

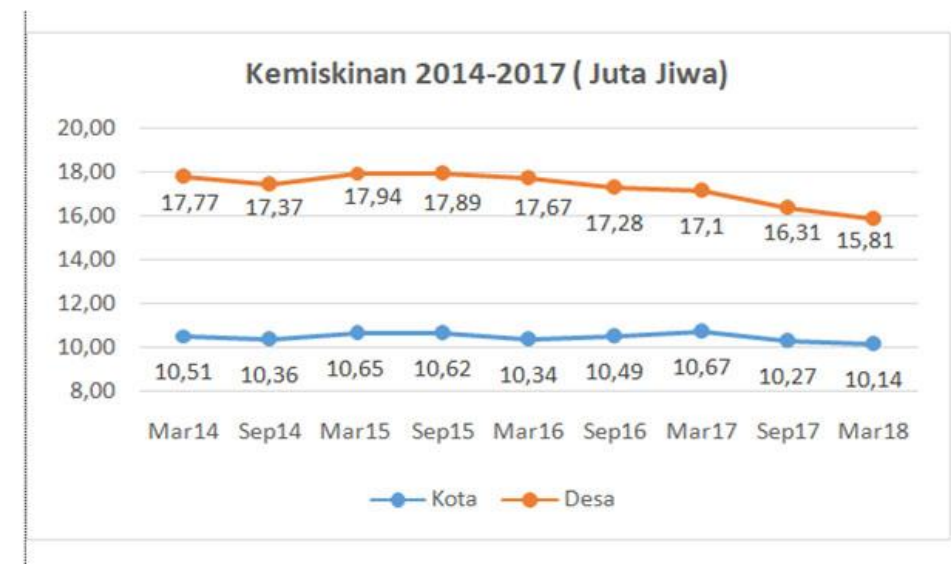

Gambar 1. Tren Kemiskinan di Indonesia

\footnotetext{
${ }^{4}$ Salah satu gejala sosial paling fundamental yang menjadi tanggung jawab pemerintah adalah problematika kemiskinan yang tidak turun secara signifikan dari waktu ke waktu, zakat hadir untuk menjadi salah satu solusi mengentaskan kemiskinan, lihat, Keumala Hayati, Zakat Potential as a Means to Overcome Poverty (A Study in Lampung), Journal of Indonesian Economy and Business, Volume 26, Number 2, h. $187-200,2011$,

${ }^{5}$ Zafar Iqbal, 2000. "Economic Rationale For The State Collection of Zakah". International Journal of Islamic Financial Services. Vol.2, no.1, April-June.

${ }^{6}$ Zainul Arifin, Dasar-dasar Manajemen Bank Syariah, (Jakarta; Alfabet, 2002) h. 3
} 
Kemiskinan sudah cenderung menurun di tingkat nasional, namun dari data BPS tersebut dijelaskan penduduk miskin desa masih tetap lebih tinggi dari miskin kota, artinya kemiskinan yang ada di tingkat yang lebih spesifik dalam hal ini di pedesaan (daerah) masih tinggi, sehingga tidak menutup kemungkinan suatu daerah dinyatakan sebagai daerah tertinggal.

Sedikitnya presentasi yang muncul dalam statistik sekitar $47 \%$, angka ini masih sangat tinggi dan perlu perhatian khusus pemerintah pusat maupun daerah yang terkait, dari penyebaran data survei yang dilakukan pemerintah, 199 kabupaten di Indonesia terdapat 33 ribu desa tertinggal yang tersebar di berbagai wilayah. Berdasarkan data Program Nasional Pemberdayaan Masyarakat Mandiri bahwasannya ada 44 kabupaten tertinggal justru muncul dari provinsi yang kondisi demografinya cukup mapan.

Provinsi Banten adalah daerah yang letaknya persis bersandingan dengan provinsi dimana letak ibukota berada saat ini. Beberapa desa yang seharusnya tidak perlu mengalami ketertinggalan dari berbagai aspek di Provinsi Banten, baik dari finansial maupun infrastruktur. Namun, realitanya hingga 2019, Kementerian Desa, Pembangunan Daerah Tertinggal dan Transmigrasi (Kemendes PDTT) masih menegaskan bahwa 364 desa di dalam Provinsi Banten masih pada status sebagai daerah tertiggal. ${ }^{7}$

Melalui skoring Indeks Desa Membangun (IDM) salah satu kabupaten yang tertinggal adalah Kabupaten Lebak. Perhitungan Kemendes PDTT melalui Direktorat Jenderal Pembangunan dan Pemberdayaan Masyarakat Desa, Indeks Ketahanan Sosial (IKS), Indeks Ketahanan Ekonomi (IKE), Indeks Ketahanan Lingkungan (IKL) masih dibawah rata-rata skor untuk dinyatakan Kabupaten Lebak dianggap sebagai daerah maju atau daerah berkembang.

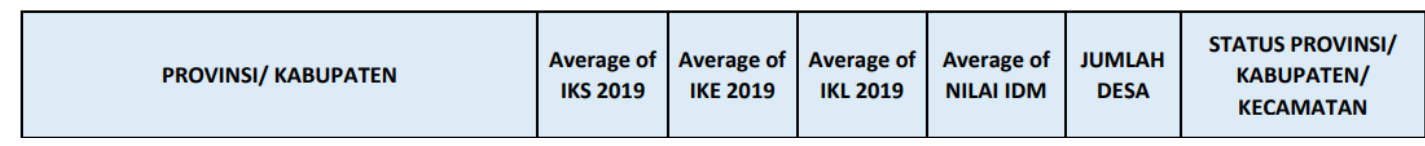

\begin{tabular}{|l|l|l|l|l|l|l|}
\hline LEBAK & $\mathbf{0 . 7 1 4 0}$ & $\mathbf{0 . 5 0 1 9}$ & $\mathbf{0 . 5 6 5 3}$ & $\mathbf{0 . 5 9 3 7}$ & $\mathbf{3 4 0}$ & TERTINGGAL \\
\hline BANJARSARI & 0.6920 & 0.4650 & 0.5433 & 0.5668 & 20 & TERTINGGAL \\
\hline BAYAH & 0.7948 & 0.5500 & 0.5152 & 0.6200 & 11 & BERKEMBANG \\
\hline BOJONGMANIK & 0.6222 & 0.4093 & 0.4817 & 0.5044 & 9 & TERTINGGAL \\
\hline CIBADAK & 0.7631 & 0.5503 & 0.5778 & 0.6304 & 15 & BERKEMBANG \\
\hline CIBEBER & 0.7223 & 0.5197 & 0.5394 & 0.5938 & 22 & TERTINGGAL \\
\hline CIGEMLONG & 0.6425 & 0.3704 & 0.5482 & 0.5203 & 9 & TERTINGGAL \\
\hline CIHARA & 0.7086 & 0.4296 & 0.6741 & 0.6041 & 9 & BERKEMBANG \\
\hline CIJAKU & 0.6023 & 0.5050 & 0.5400 & 0.5491 & 10 & TERTINGGAL \\
\hline CIKULUR & 0.7187 & 0.5090 & 0.5897 & 0.6058 & 13 & BERKEMBANG \\
\hline CILELES & 0.7362 & 0.4597 & 0.6000 & 0.5986 & 12 & TERTINGGAL \\
\hline
\end{tabular}

Gambar 2. Indeks Desa Membangun Kemendes PDTT

7 Kemendes Rilis 364 Desa Tertinggal, Lebak Dan Pandeglang Terbanyak http://www.rmolbanten.com/read/2019/11/04/12724/Kemendes-Rilis-364-Desa-Tertinggal,-Lebak-DanPandeglang-Terbanyak- 


\section{B. METODE PENELITIAN}

Makalah ini menggunakan pendekatan analisis hukum normatif yaitu penelitian hukum dengan menganalisis bahan pustaka atau bukti sekunder sebagai tugas utama. Analisis hukum normatif adalah metode penelitian ilmiah untuk menemukan fakta berdasarkan penalaran ilmiah hukum dari sudut pandang normatif (Soekanto, 2015: 1314). Dengan demikian kajian ini berangkat dari perspektif asas hukum positif yang berkaitan dengan kerangka hukum nasional perundang-undangan (Marzuki, 2016: 59). Metode yang digunakan adalah pendekatan etis dan pendekatan kasus. Bukti sekunder utamanya diambil dari peraturan perundang-undangan tentang pemberantasan perbuatan salah dan putusan pengadilan sebagai muatan hukum utama. Data yang terkumpul kemudian dievaluasi secara kualitatif.

\section{ANALISIS DAN PEMBAHASAN}

\section{Kontribusi Hukum Pengelolaan Zakat untuk Pembangunan Daerah}

Zakat sebagai salah satu dari filantropi Islam mengalami pertumbuhan yang sangat pesat. Keberadaan zakat dipandang sebagai sarana komunikasi utama antara manusia dengan manusia lain dalam masyarakat, artinya zakat memiliki peranan yang sangat penting dalam menyusun kehidupan yang sejahtera dan berkeadilan di dalam sebuah negara. ${ }^{8}$ Karena zakat cukup menjadi peranan penting sebagai objek yang meningkatkan kesejahteraan masyarakat, maka dalam pengelolaannya harus memperhatikan asas dan tujuan pengelolaan zakat dengan berdasarkan pengelolaan zakat yang berasaskan syariat Islam, amanah, kemanfaatan, keadilan, kepastian hukum, terintegrasi, dan akuntabilitas. ${ }^{9}$

Selain itu, pengelolaan zakat ini harus bertujuan untuk meningkatkan efektivitas dan efisiensi pelayanan dalam pengelolaan zakat dan meningkatkan manfaat zakat untuk penanggulangan kemiskinan. ${ }^{10}$ Zakat memberikan hikmah dan manfaat yang besar dan mulia baik bagi orang yang berzakat, penerima zakat, harta yang dikeluarkan zakatnya, maupun bagi masyarakat keseluruhan. ${ }^{11}$ Hal itu merupakan salah satu instrumen pemerataan pendapatan. Pengelolaan zakat yang baik maka dapat meningkatkan pertumbuhan ekonomi sekaligus pemerataan pendapatan..$^{12}$

Salah satu strategi mengelola pendapatan instrumen ekonomi yang berasal dari zakat, caranya adalah mendesain kontruksi hukum untuk menjadi dasar bergeraknya pengelolaan zakat baik secara nasional maupun secara lokal disetiap daerah. Tidak hanya untuk memaksimalkan apa yang didapat dan dikelola oleh pengelola zakat

${ }^{8}$ Zuziana Elly Triantini, “Perkembangan Pengelolaan Zakat di Indonesia”, Al-Ahwal, vol.3, no.1 (2010): 91.

9 Pasal 2 UU No. 23 Tahun 2011 tentang Pengelolaan Zakat.

${ }^{10}$ Pasal 3 UU No. 23 Tahun 2011 tentang Pengelolaan Zakat.

${ }^{11}$ Abdurrahman Qadir, Zakat dalam Dimensi Mahdhah dan Sosial, (Jakarta: PT Raja Grafindo Persada, 1998), 82.

${ }^{12}$ Ahmad Muflih Saefuddin, Pengelolaan Zakat ditinjau dari Aspek Ekonomi (Bontang: Badan Dakwah Islamiyyah, LNG, 1986), 99. 
(amil), ${ }^{13}$ namun untuk kepastian hukum penyaluran zakat kepada pihak-pihak penerima zakat (mustahik), dan pada akhirnya bentuk pemerataan pendapatan kepada mereka tidak disalahgunakan sehingga menjadi preseden yang baik demi mewujudkan sistem yang berkelanjutan.

Amanat konstitusi tegas bahwa memang kesejahteraan masyarakat adalah tanggung jawab pemerintah pusat. Sebagai perwujudan cita-cita yang luhur, maka Indonesia yang memiliki karakteristik bangsanya menjadi negara hukum dibentuklah regulasi yang melaksanakan salah satu instrumen ekonomi yakni Undang-undang Nomor 23 Tahun 2011 tentang Pengelolaan Zakat. Pada penjelasan ini dijelaskan bahwa zakat sebagai tradisi keagamaan yang dikodifikasikan dalam 'baju hukum' undangundang, untuk menciptakan keadilan dan kesejahteraan rakyat. Lebih dari itu undangundang pengelolaan zakat diberikan amanah untuk menciptakan adanya suatu lembaga atau institusi zakat demi mengentaskan kemiskinan di beberapa daerah, sehingga dapat meningkatkan daya guna dan daya hasil guna sesuai syariat Islam. ${ }^{14}$

Pemerintah pusat dalam mengelola zakat diberikan kepada suatu badan otonom khusus dengan menggunakan nomenklatur Badan Amil Zakat Nasional (BAZNAS) baik untuk ditingkat pusat maupun untuk di tingkat daerah, artinya di daerah saat ini juga merujuk pada satu regulasi yang menyatu atapkan pengelolaan zakat pada satu badan, sehingga di daerah telah terbentuk pula lembaga BAZNAS yang sifatnya desentralisasi agar menciptakan sistem pengelolaan zakat yang efektif dan efisien melalui sistem hirarki kelembagaan badan pengelola zakat di Indonesia. ${ }^{15}$

Rangkaian sejarah terbentuknya regulasi zakat hingga saat ini, prinsipnya tidaklah singkat, karena selain kebutuhan hukum pengelolaan zakat didaerah yang belum terakomodir pada pembentukan undang-undang pengelolaan zakat pertama kali yang dituangkan pada nomor 38 tahun 1999. Pemerintah Pusat bersama DPR juga bersepakat untuk merevisi undang-undang lama menjadi undang-undang baru yang mengakomodir seluruh pengelolaan zakat tidak hanya yang dimiliki oleh pemerintah, namun pengelolaan zakat yang dimiliki oleh badan usaha milik negara maupun perusahaan swasta juga diatur pada satu atap regulasi.

Hingga akhirnya terbentuk satu regulasi pengelolaan zakat yang baru dan juga belum diterima oleh para pelaku pengelola zakat di tanah air. Kebijakan ini juga mengalami pengujian undang-undang (judicial review) dari kekeliruan perumusan sampai terindikasi adanya celah hukum yang terbuka yang membuat makna dan definisi pada undang-undang nomor 23 tahun 2011 terlalu luas kemudian diajukan banding oleh Lembaga Amil Zakat (LAZ) dan masyarakat yang tidak sejalan dengan terbitnya undang-undang tersebut. Melalui putusan Mahkamah Konstitusi (MK) Nomor 86/PUU-X/2012 perihal pengujian Undang-Undang Nomor 23 Tahun 2011

${ }^{13}$ Suprima, Holilur Rahman, Regulasi Pengelolaan Zakat Di Indonesia, Jurnal Yuridis Vol. 6 No. 1, Juni 2019 : $132-146$

${ }^{14}$ Penjelasan Umum Undang-undang Nomor 23 Tahun 2011 tentang Pengelolaan Zakat

15 Mufida, Sistem Hirarki Kelembagaan Badan Pengelola Zakat di Indonesia (Tinjauan Terhadap Pelaksanaan Undang-Undang Nomor 23 Tahun 2011), Jurnal Cita Hukum, Fakultas Syariah dan Hukum UIN Jakarta Vol.4 No.2(2016), pp.323-344, 
tentang Pengelolaan Zakat. ${ }^{16}$ Seluruh pemangku kepentingan pengelolaan zakat harus mentaati dan melaksanakan amanat putusan tersebut, termasuk seluruh pengelola zakat di daerah baik pemerintah maupun swasta.

Pengelola zakat yang dimiliki pemerintah daerah bersumber dari kewenangan atribusi Pasal 15 Undang-Undang Nomor 23 Tahun 2011 tentang pembentukan BAZNAS Provinsi dan Kabupaten/Kota. Dari semua fungsi dan tugas yang di amanahkan kepada BAZNAS ditingkat pusat, maka dilaksanakan pula oleh BAZNAS di tingkat daerah. undang-undang pengelolaan zakat memerintahkan, bahwa BAZNAS bertugas dan memiliki fungsi untuk; pertama, merencanakan pengumpulan, pendistribusian, dan pendayagunaan zakat; kedua, melaksanakan pengumpulan pendistribusian dan pendayagunaan zakat; ketiga, mengendalikan pengumpulan pendistribusian dan pendayagunaan zakat, hingga keempat, pelaporan dan pertanggung jawaban pelaksanaan pengelolaan zakat.

\section{Pengelolaan Zakat untuk Pembangunan Daerah Tertinggal}

Sebagai negara berkembang, masalah mengenai kemiskinan masih terjadi di Indonesia. Belum meratanya perekonomian dan pembangunan menjadi salah satu pekerjaan rumah bagi Indonesia. Disisi lain, zakat selama ini masih dianggap sebelah mata, padahal Indonesia yang mayoritas penduduknya Muslim memiliki potensi zakat yang sangat besar jumlahnya. Potensi zakat yang besar ini dapat digunakan sebagai instrumen keagamaan untuk menunjang pembangunan daerah tertinggal apabila dikelola dengan optimal. Pada tahun 2018, jumlah desa tertinggal berkurang sebanyak 6.518 desa dimana berdasarkan Perpres No. 131 Tahun 2015.17 Target pemerintah adalah 5000 desa, $^{18}$ artinya pemerintah pusat dan daerah dalam hal ini berhasil melampaui target, dan hal tersebut bisa digunakan untuk pembangunan daerah tertinggal.

Untuk lebih terperinci, selama ini praktik pendistribusian zakat lebih didominasi kepada zakat konsumtif. Sehingga zakat yang disalurkan ke masyarakat hanya dapat digunakan dalam kurun waktu singkat. Tujuan zakat sebenarnya tidak sekedar menyantuni orang miskin secara konsumtif, tetapi mempunyai tujuan yang lebih permanen yaitu mengentaskan kemiskinan. ${ }^{19}$ Penting kiranya menjaga stabilitas ekonomi yang dilakukan oleh pemerintah, salah satu tujuannya adalah menurunkan indeks kemiskinan yang ada di Indonesia. Maka dari itu, program zakat saat ini lebih difokuskan pada zakat produktif. Zakat produkif adalah pemberian zakat yang dapat membuat para penerimanya menghasilkan sesuatu secara terus menerus, dengan harta

\footnotetext{
${ }^{16}$ Mustolih Siradj, Jalan Panjang Legislasi Syariat Zakat di Indonesia: Studi terhadap Undang-Undang Nomor 23 tahun 2011 tentang Pengelolaan Zakat, Jurnal Bimas Islam Vol.7. No.III 2014, h. 409-448.

17 Peraturan Presiden Nomor 131 Tahun 2015 tentang Penetapan Daerah Tertinggal Tahun 20152019

18 Murti Ali Lingga, BPS: Jumlah Desa Tertinggal Berkurang 6.518 Desa, https://ekonomi.kompas.com/read/2018/12/10/133742026/bps-jumlah-desa-tertinggal-berkurang-6518-desa (diakses pada tanggal 17 Februari 2020).

19 Siti Aminah Chaniago, Pemberdayaan Zakat Dalam Mengentaskan Kemiskinan, Jurnal Hukum Islam (JHI), Volume 13, Nomor 1, Juni 2015, (47-56)
} 
zakat yang telah diterimanya. ${ }^{20}$ Beberapa program zakat yang digunakan untuk kegiatan produktif seperti untuk hal-hal yang berkaitan dengan peningkatan mutu pendidikan, pelayanan kesehatan, pemberian modal usaha, dan lain sebagainya.

Salah satu cara BAZNAS melalui lembaga pusat kajian strategisnya memberikan tolak ukur dengan menggunakan Indeks Desa Zakat (IDZ), Prinsip Indeks ini adalah alat untuk menguji apakah dalam suatu daerah (termasuk wilayah perkampungan di desa) dapat diberikan bantuan oleh lembaga pengelola zakat atau tidak. Baik untuk program zakat produktif atau program kegiatan yang lainnya. Sebagai asessment awal indeks desa zakat adalah data yang perlu dipersiapkan untuk prioritas dalam suatu wilayah. Pemerintah daerah dalam hal ini melalui 'tangan' BAZNAS daerah Provinsi atau Kabupaten/Kota dapat menggunakan indeks tersebut melalui beberapa komponen indeks yang telah ditentukan. ${ }^{21}$

Sesuai urgensitas perannya, kegiatan perencanaan, pelaksanaan, dan pengkoordinasian dalam pengumpulan, pendistribusian, dan pendayagunaan zakat adalah potensi ekonomi yang perlu dioptimalkan oleh lembaga pengelola zakat. Secara signifikan zakat sebagai bagian dari kebijakan fiskal dianggap sebagai sendi ekonomi diberbagai negara, sehingga dalam penerapannya memunculkan berbagai macam cara pengelolaan untuk memberikan dampak ekonomi yang maksimal.22

\section{Kontribusi Zakat Kabupaten Lebak Provinsi Banten untuk Pembangunan Tertinggal}

Peluang penggunaan zakat, acap kali menjadi diskursus tersendiri, dalam literatur hukum Islam, Peluang zakat menjadi bagian yang diatur berdasarkan nash (sumber utama) umat Muslim dalam bermuamalah, yakni Al-Qur'an dan Hadits, sedangkan di Indonesia peluang zakat dimanfaatkan secara maksimal perwujudannya melalui dituangkannya rujukan umat Muslim tersebut kepada hukum positif (undangundang), oleh karena itu implementasi zakat diberlakukan tidak lagi hanya berdasarkan keyakinan dalam aspek keagamaan iman dan takwa, namun pemberlakuannya didasari oleh kekuatan regulasi dan hierarki peraturan perundang-undangan dari tingkat pusat hingga regulasi di tingkat daerah. ${ }^{23}$

Regulasi di tingkat daerah sangat penting di terapkan untuk meningkatkan potensi zakat, khusunya daerah yang diklaim pemerintah sebagai daerah tertinggal. Kabupaten Lebak, Provinsi Banten, adalah salah satunya. Regulasi yang dibutuhkan dalam memaksimalkan potensi zakat di Kabupaten Lebak Banten prinsipnya belum

${ }^{20}$ Asnaini, Zakat Produktif dalam Perspektif Hukum Islam (Yogyakarta: Putaka Pelajar, 2008).

21 Aspek komponennya adalah ekonomi, Kesehatan, Pendidikan, Sosial dan Kemanusiaan, serta komponen terakhir yaitu Dakwah, Tim Riset Dan Kajian Puskas Baznas (2017) Indeks Desa Zakat, Dari Desa Untuk Zakat Yang Terukur Dan Berkemajuan, Puskas Baznas, Jakarta. Hal. 8

22 Amiruddin K, Model-Model Pengelolaan Zakat Di Dunia Muslim, AHKAM, Volume 3, Nomor 1, Juli 2015: 139-166

${ }^{23}$ Mohammad Daud Ali, Hukum Islam Pengantar Hukum Islam dan Tata Hukum Islam di Indonesia, 2002, Jakarta : Raja Grafindo Persada. h. 5-6 
memadai. Sehingga dibutuhkan reformulasi baru dalam regulasi untuk pengelolaan zakat.

Kurang kuatnya regulasi dalam pengelolaan zakat pada Kabupaten Lebak dapat dilihat dari perkembangan sumber daya zakat yang setiap tahunnya mengalami penurunan.

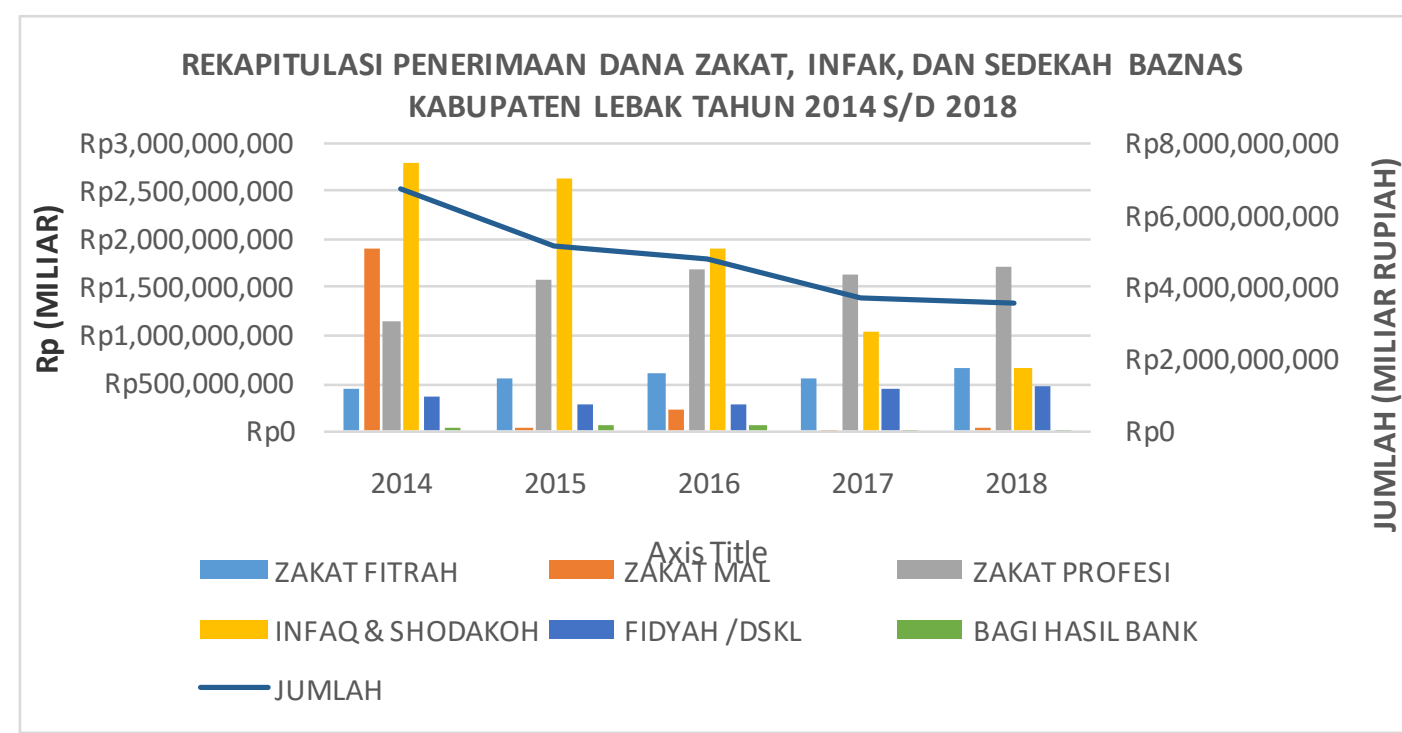

Gambar 3. Penerimaan Zakat Kabupaten Lebak Provinsi Banten. ${ }^{24}$

Rangkaian penerimaan dana zakat yang di kelola dari berbagai sumber pendanaan, telah dilakukan oleh semua pemangku kepentingan (stakeholders) pengelola zakat, hal ini di buktikan dengan berjalannya berbagai macam kegiatan dan target-target yang telah di tentukan setiap tahunnya, dari perencanaan, pengelolaan, hingga pendistribusian zakat di Kabupaten Lebak, telah dirasakan manfaatnya oleh masyarakat daerah Kabupaten Lebak. Di sisi lain pengelola zakat masih terus berusaha untuk memaksimalkan potensi yang ada, jika dilihat dari grafik, hingga catatan tahun terakhir dana yang didapat tidak lebih dari 5 milyar yang telah ditentukan di awal target yang ingin dicapai, kenyatannya justru mengalami penurunan menjadi 3,5 milyar sejak dimulainya dari tahun 2014. Akar masalah ini terjadi berawal dari kekuatan seorang penguasa, perkembangan pengelolaan dana zakat apabila ingin mengalami kenaikan itu bisa menjadi besar secara signifikan dilihat dari kekuatan penguasa (power of leadership). Hal Ini sangat mempengaruhi pengelolaan zakat, dan prinsipnya sangat bergantung kepada bagaimana penguasa terhadap political will dari pemerintah setempat besar atau kecil.

Hasil dari pengelolaan dana zakat Kabupaten Lebak menurut peneliti sudah dapat banyak membantu untuk pembangunan daerah. Sepak terjang BAZNAS Lebak dapat dilihat hasilnya pada setiap wilayah kecamatan dan desa yang ada. Secara demografi Kabupaten Lebak memiliki 1.302 .608 (satu juta tiga ratus dua ribu enam ratus

${ }^{24}$ Data Diterima dari Kantor Bagian Administrasi Umum Badan Amil Zakat kabupaten Lebak 
delapan) jiwa penduduk, dari pembagian jenis kelamin terdapat 666.802 (enam ratus enam puluh enam ribu delapan ratus dua) untuk laki-laki dan 635.806 (enam ratus tiga puluh lima ribu delapan ratus enam) untuk perempuan. ${ }^{25}$ Seluruh penduduk Kabupaten Lebak, menurut pengurus BAZNAS Lebak sudah mencapai 70\% mendapatkan distribusi dari bantuan pengelolaan dana zakat, baik yang bersifat materiil maupun kegiatan BAZNAS Lebak yang tidak bersifat immaterii, ${ }^{26}$ seperti kegiatan keagamaan yang dilaksanakan namun pengelolaannya bersumber dari dana BAZNAS Lebak.

Hasil laporan tersebut kemudian dilapokan setiap 6 bulan sekali, pada bulan Juni dan akhir Desember. Laporan ini diberikan kepada setiap kantor kecamatan dan kantor desa yang termasuk dalam wilayah di Kabupaten Lebak. Untuk meningkatkan taraf pertanggung jawaban pengelolaan zakat yang dilakukan oleh BAZNAS Lebak. Secara mandiri lembaga BAZNAS Lebak dibantu oleh akuntan publik swasta untuk memonitoring dan evaluasi finansial keuangan BAZNAS Lebak. Hasil dari akuntan publik kemudian dikonversi kepada bagian dari bentuk laporan kepada masyarakat yang telah membayar zakat.

Beberapa kegiatan yang awalnya pernah dilakukan oleh Badan Amil Zakat Daerah (BAZDA) Lebak hari ini pasca pergantian pengurus dari komisioner hingga pegawai, dilakukan kembali dengan nominal pemungutan dana zakat sedikit lebih besar, contohnya kegiatan infak sedekah yang diambil langsung dari gaji pegawai pemerintah baik yang PNS (Pegawai Negeri Sipil) maupun Non PNS. Infak dan sedekah yang dahulu dipungut sebesar Rp2000 (dua ribu rupiah) saat ini menjadi Rp5000 (lima ribu rupiah) setiap bulannya. Namun regulasi pungutan dana ini masih dalam bentuk surat edaran sehingga tidak cukup kuat untuk kemudian dilaksanakan oleh aparatur sipil negara di Kabupaten Lebak, atas dasar tersebut regulasi pengelolaan zakat daerah prinsipnya sangat dibutuhkan oleh BAZNAS Lebak sebagai salah satu garda terdepan dalam berkontribusi pembangunan daerah. Perubahan status Kabupaten Lebak dari daerah tertinggal menjadi daerah yang lebih maju tentunya tidak terlepas dari pemerataan pembangunan di daerah setempat dan juga peran instrumen zakat.

Pengelolaan zakat di Kabupaten Lebak Banten terus dikembangkan salah satunya, ketua BAZNAS Kabupaten Lebak menargetkan untuk mendapatkan potensi zakat sebesar 600 juta. ${ }^{27}$ Untuk mencapai target tersebut dibutuhkan pengelolaan zakat yang tepat. Mengenai pengelolaan zakat di Kabupaten Lebak diatur dalam Peraturan Daerah Kabupaten Lebak Nomor 11 Tahun 2005 tentang Pengelolaan Zakat. Dana zakat yang terkumpul nantinya akan disalurkan ke masyarakat dan dipastikan untuk

${ }^{25}$ Lihat, Penduduk Menurut Jenis Kelamin dan Kabupaten/Kota di Provinsi Banten, 2005-2019 https://banten.bps.go.id/dynamictable/2015/09/07/51/penduduk-menurut-jenis-kelamin-dan-kabupatenkota-di-provinsi-banten-2005-2019.html

${ }^{26}$ Lebih detail kegiatan imateriil yang dimaksud oleh narasumber adalah kegiatan yang bersifat umum pada waktu hari raya besar Islam. Artinya semua kegiatan dilakukan namun tidak langsung secara meteriil, namun kegiatan tersebut di isi oleh seluruh anggota baznas dari rangkaian acara hingga konsumsi dan sebagainya seluruh kebutuhan kegiatan acara tersebut

${ }^{27}$ Baznas Lebak targetkan penerimaan zakat Rp600 Juta

https://banten.antaranews.com/berita/44936/baznas-lebak-targetkan-penerimaan-zakat-rp600-juta diakses pada tanggal 29 juli 2019 
kesejahteraan umat. ${ }^{28}$ Sementara itu, sasaran utama dari BAZNAS Kabupaten Lebak untuk sementara ini adalah Aparatur Sipil Negara (ASN). Dimana nantinya dana zakat yang terkumpul akan dilaporkan terlebih dahulu ke BAZNAS dan kemudian dana tersebut akan dibagikan ke masyarakat miskin disetiap desa. Misalnya, dana zakat yang tertampung sebesar Rp630.000.000 maka dana tersebut akan dibagikan ke 100 orang miskin disetiap desa masing-masing Rp40.000 per orang. Akan tetapi pada tahun 2019, orang yang berhak menerima dana zakat tersebut hanya diberi Rp30.000 per orang. Jumlah tersebut lebih sedikit dibandingkan pada tahun 2018 yang mana setiap orang diberi Rp40.000. Hal ini dikarenakan penyaluran dana zakat disesuaikan dengan besarnya zakat yang terkumpul.

Di Kabupaten Lebak, zakat juga turut memberikan kontribusinya untuk pembangunan Kabupaten Lebak yang lebih difokuskan untuk pendidikan, kesehatan, kemanusiaan, ekonomi, dan dakwah advokasi. Melalui BAZNAS Kabupaten Lebak, dana zakat yang terhimpun tersebut disalurkan ke masyarakat yang membutuhkan.

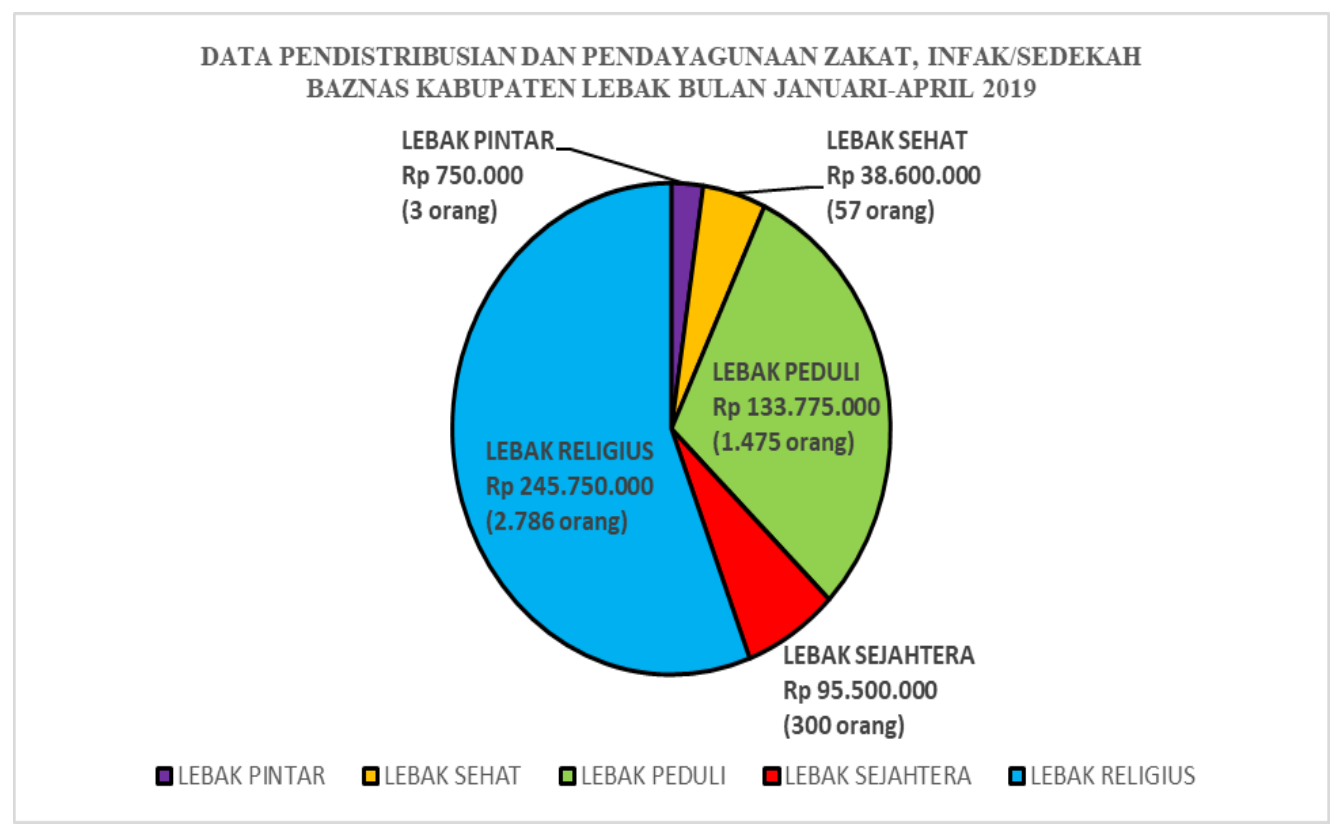

Gambar 4. Data pendistribusian dana zakat di Kabupaten Lebak.

Zakat telah menjadi salah satu upaya yang digunakan pemerintah untuk pemerataan pembangunan dan pendapatan masyarakat, dalam hal ini turut memberikan kontribusinya terhadap kesejahteraan masyarakat di Kabupaten Lebak melalui program-program yang dilakukan oleh BAZNAS Kabupaten Lebak.

\footnotetext{
28 Baznas bebak bejahterakan umat https://banten.antaranews.com/berita/36489/baznas-lebak-berkomitmen-sejahterakan-umat 


\section{KESIMPULAN}

Pengelolaan zakat pada daerah tertinggal seperti Kabupaten Lebak sangat dibutuhkan kontribusinya, sebagai salah satu instrumen yang kuat dibidang finansial dan keuangan, potensi zakat sangat siginifikan membantu perkembangan pembangunan suatu daerah, terlebih lagi dari berbagai macam kegiatan yang di implementasikan untuk mencapai target-target yang ditentukan. Pengelolaan zakat akan semakin berkembang apabila memiliki regulasi yang kuat dalam suatu daerah, hal ini menunjukan bahwa sinergitas antara pengelola zakat dengan pemerintah daerah yang sedang aktif perlu ditingkatkan dengan berbagai macam pola program kerja yang bervariasi.

BAZNAS Lebak Banten telah melakukan berbagai macam inovasi kegiatan yang terdiri dari Lebak Pintar, Lebak Sehat dan Lebak Sejahtera. Kegiatan tersebut adalah kegiatan positif yang perlu didukung oleh pendanaan zakat. Sehingga dana yang dikelola menjadi efektif dan efisien. Jika pendanaan tersebut telah di salurkan kepada berbagai macam kegiatan pemerintah daerah, sebagai pertanggung jawabannya kontribusi zakat bisa dilakukan dalam bentuk laporan yang disampaikan kepada perwakilan masyarakat yang ada di setiap desa atau kecamatan dalam hal ini kantor desa dan kantor kecamatan. Kemudian masyarakat dapat mempercayai lembaga BAZNAS Lebak yang menjadi dasar peningkatan jumlah dana zakat pada masa yang akan datang.

\section{REFERENSI:}

\section{BUKU / JURNAL}

Ahmad Ziauddin, Islam, poverty and income distribution : a discussion of the distinctive Islamic approach to eradication of poverty and achievement of an equitable distribution of income and wealth, Islamic economics series ; 15. S (Leicester, UK,: Islamic Foundation, 1991.

Ali, Mohammad Daud, Hukum Islam Pengantar Hukum Islam dan Tata Hukum Islam di Indonesia, Jakarta : Raja Grafindo Persada. 2002

Aminah Siti Chaniago, Pemberdayaan Zakat Dalam Mengentaskan Kemiskinan, Jurnal Hukum Islam (JHI), Volume 13, Nomor 1, Juni 2015

Arifin Zainul, Dasar-dasar Manajemen Bank Syariah, Jakarta; Alfabet, 2002.

Asnaini, Zakat Produktif dalam Perspektif Hukum Islam, Yogyakarta: Putaka Pelajar, 2008

Chusainul Adib, Peran Negara Dalam Pengelolaan Zakat Umat Islam di Indonesia, Jurnal Nestor Magister Hukum, Vol 1, No 12017

Firmansyah, "Zakat Sebagai Instrumen Pengentasan Kemiskinan dan Kesenjangan Pendapatan”, Jurnal Ekonomi Pembangunan, Vol. 21, No. 2 (Desember 2013), 182.

Hayati Keumala, Zakat Potential As A Means To Overcome Poverty (A Study In Lampung), Journal of Indonesian Economy and Business, Volume 26, Number 2, 2011. 
Holilur Rahman, Suprima, Regulasi Pengelolaan Zakat Di Indonesia, Jurnal Yuridis Vol. 6 No. 1, Juni 2019

Iqbal Zafar,. "Economic Rationale For The State Collection of Zakah". International Journal of Islamic Financial Services. Vol.2, no.1, April-June 2010.

Jamil Alfan, Implementasi Indeks Desa Zakat Pada Desa Sungai Dua Kecamatan Rambutan (Untuk Desa yang Terukur dan Berkemajuan), KHOZANA: Jurnal Ekonomi dan Perbankan Islam, Vol. 1, No. 2, Juli 2018,

K Amiruddin, Model-Model Pengelolaan Zakat Di Dunia Muslim, AHKAM, Volume 3, Nomor 1, Juli 2015

Kemeterian Desa dan Transmigrasi, Status Indeks Desa Membangun Provinsi Kabupaten Kecamatan Tahun 2019. Direktorat Jenderal Pembangunan dan Pemberdayaan Masyarakat Desa, Kementerian Desa, Pembangunan Daerah Tertinggal dan Transmigrasi Republik Indonesia.

Maggalatung, A.S.; Aji, A.M.; Yunus, N.R. How The Law Works, Jakarta: Jurisprudence Institute, 2014.

Mubarok, Abdullah dan Baihaqi Fanani, "Penghimpunan Dana Zakat Nasional (Potensi, Realisasi, dan Peran Penting Organisasi Pengelola Zakat)", PERMANA, Vol. V, No.2, Februari 2014.

Mufida, Sistem Hirarki Kelembagaan Badan Pengelola Zakat Di Indonesia (Tinjauan Terhadap Pelaksanaan Undang-Undang Nomor 23 Tahun 2011), Jurnal Cita Hukum, Fakultas Syariah dan Hukum UIN Jakarta Vol.4 No.2, 2016.

Mukri, S.G.; Aji, A.M.; Yunus, N.R. Relation of Religion, Economy, and Constitution In The Structure of State Life, STAATSRECHT: Indonesian Constitutional Law Journal, Volume 1, No. 1. (2017).

Qadir, Abdurrahman, Zakat dalam Dimensi Mahdhah dan Sosial, (Jakarta : PT Raja Grafindo Persada, 1998

Rezki, Annissa; Anggraeni, RR. Dewi; Yunus, Nur Rohim. "Application of Civil Law Theory In the Termination of Custody of Adopted Children in Indonesia," Journal of Legal Research, Volume 1, No. 6 (2019).

Saefuddin, Ahmad Muflih, Pengelolaan Zakat ditinjau dari Aspek Ekonomi (Bontang : Badan Dakwah Islamiyyah, LNG, 1986

Siradj Mustolih, Jalan Panjang Legislasi Syariat Zakat di Indonesia: Studi terhadap UndangUndang Nomor 23 tahun 2011 tentang Pengelolaan Zakat, Jurnal Bimas Islam Vol.7. No.III 2014,

Tim Riset Dan Kajian Puskas Baznas Indeks Desa Zakat, Dari Desa Untuk Zakat Yang Terukur Dan Berkemajuan, Puskas Baznas, Jakarta, 2017.

Triantini Zuziana Elly, "Perkembangan Pengelolaan Zakat di Indonesia", Al-Ahwal, vol.3, No.1, 2010. 


\section{WAWANCARA}

Hasil Wawancara dengan Komisioner Baznas Bpk Adibul Wathon Wakil Ketua Komisioner Badan Amil Zakat Nasioal Kabupaten Lebak. 19 September 2019 di kantor Baznas Lebak

\section{PERATURAN PERUNDANG-UNDANGAN}

Undang Undang Nomor 23 Tahun 2011 tentang Pengelolaan Zakat.

Peraturan Presiden Nomor 131 Tahun 2015 tentang Penetapan Daerah Tertinggal Tahun 2015-2019

Surat Keputusan Direktorat Jenderal dan Pemberdayaan Masyarakat Desa Nomor 201 Tahun 2019 tentang perubahan kedua atas keputusan Direktur Jenderal Pembangunan dan Pemberdayaan Masyarakat Desa Nomor 30 Tahun 2016 Tentang Status Kemajuan dan Kemandirian Desa

\section{INTERNET (DARING ONLINE)}

Penduduk Menurut Jenis Kelamin dan Kabupaten/Kota di Provinsi Banten, 2005-2019 https://banten.bps.go.id/dynamictable/2015/09/07/51/penduduk-menurut-jeniskelamin-dan-kabupaten-kota-di-provinsi-banten-2005-2019.html

Baznas Lebak targetkan penerimaan zakat Rp600 Juta https://banten.antaranews.com/berita/44936/baznas-lebak-targetkanpenerimaan-zakat-rp600-juta,

Baznas Lebak Banten Bagikan 27.850 Penerima Zakat https://www.industry.co.id/read/36129/baznas-lebak-banten-bagikan-27850penerima-zakat

Baznas Lebak berkomitmen sejahterakan umat https://banten.antaranews.com/berita/36489/baznas-lebak-berkomitmensejahterakan-umat

Penduduk Desa Masih Lebih Miskin Daripada Penduduk Kota https://spi.or.id/penduduk-desa-masih-lebih-miskin-daripada-penduduk-kota/ diakses pada 19 Januari 2019

Kemendes Rilis 364 Desa Tertinggal, Lebak Dan Pandeglang Terbanyak http://www.rmolbanten.com/read/2019/11/04/12724/Kemendes-Rilis-364-DesaTertinggal,-Lebak-Dan-Pandeglang-Terbanyak-

Penduduk miskin menurun pada angka 2. 2,59 juta jiwa dibanding posisi September 2014, lihat , https://databoks.katadata.co.id/datapublish/2019/10/17/5-tahunpertama-kepemimpinan-jokowi-angka-kemiskinan-turun-155-bps di akses pada tanggal 1 April 2019.

Murti Ali Lingga, BPS: Jumlah Desa Tertinggal Berkurang 6.518 Desa, https://ekonomi.kompas.com/read/2018/12/10/133742026/bps-jumlah-desatertinggal-berkurang-6518-desa diakses pada tanggal 17 Februari 2020 
Muhammad Helmi Fahrozi, Suprima, Rostania Nur Asiyah

Khairunnajah, Peran Baznas dalam Pembangunan Wilayah Tertinggal, https://sharianews.com/posts/peran-baznas-dalam-pembangunan-wilayahtertinggal (diakses pada tanggal 17 Februari 2020). 